Article

\title{
Komposisi Nilai Gizi Pempek Ikan Tenggiri (Scomberomorus Commersonii) Dengan Penambahan Wortel (Daucus Carota)
}

\section{Nutrient Composition of Mackerel (Scomberomorus commersonii) Pempek with Carrots (Daucus carota)}

\author{
Nur Endah Saputri ${ }^{1 *}$, Nurul Hidayah ${ }^{2}$, Yuges Saputri Muttalib ${ }^{2}$ \\ ${ }^{1}$ Program Studi Teknologi Pangan, Universitas Tanjungpura, Pontianak, Indonesia \\ ${ }^{2}$ Program Studi Gizi, Universitas Esa Unggul, Jakarta, Indonesia
}

(*nur.endah@faperta.untan.ac.id)

\begin{abstract}
ABSTRAK
Asupan serat pangan pada anak-anak di Indonesia cukup rendah. Modifikasi kudapan atau makanan sepinggan dengan penambahan sayur dapat menjadi salah satu upaya peningkatan asupan serat pangan. Penelitian ini mengkaji karakteristik nilai gizi serta penerimaan sensori pempek ikan tenggiri dengan penambahan wortel. Studi eksperimental dengan Rancangan Acak Lengkap (RAL). Terdapat empat formulasi pempek, yaitu F1 (0\% wortel), F2 (20\% wortel), F3 (40\% wortel), dan F4 (60\% wortel). Penambahan $40 \%$ wortel mampu meningkatkan nilai penerimaan sensori terbaik pada warna $(6,7 \pm 1,7)$, aroma $(5,8 \pm 2,4)$, tekstur $(6,7 \pm 1,7)$, dan rasa $(6,8 \pm 1,6)$. Kemudian, komposisi nilai gizi pempek dengan penambahan $40 \%$ wortel yaitu air $(66,52 \pm 0,57 \%)$, abu $(1,77 \pm 0,05 \%)$, lemak $(<0,02 \%)$, protein $(7,43 \pm 0,01 \%)$, karbohidrat $(24,25 \pm 0,63 \%)$, dan serat pangan $(2,42 \pm 0,01 \%)$. Penambahan wortel dapat meningkatkan penerimaan sensori serta kadar air dan serat pangan.
\end{abstract}

Kata kunci : Pempek, Ikan Tenggiri, Wortel, Nilai Gizi

\section{ABSTRACT}

Dietary fiber intake among Indonesian children is quite low. Modification of snacks or side dishes with the addition of vegetables can be an effort to elevate dietary fiber intake. This study examined the nutritional value and sensory acceptance of mackerel fish pempek with carrots. It was an experimental study with a completely randomized design (CRD). There were four formulations of pempek, F1 (0\% carrots), F2 (20\% carrots), F3 (40\% carrots), and F4 (60\% carrots). The addition of $40 \%$ carrots was able to improve the value of the best sensory acceptance on color $(6.7 \pm 1.7)$, aroma (5.8 \pm 2.4$)$, texture $(6.7 \pm 1.7)$, and taste $(6.8 \pm 1.6)$. Then, the composition of the nutritional value of pempek with $40 \%$ carrots was including water $(66.52 \pm 0.57 \%)$, ash $(1.77 \pm 0.05 \%)$, fat $(<0.02 \%)$, protein $(7.43 \pm 0.01 \%)$, carbohydrates $(24.25 \pm 0.63 \%)$, and dietary fiber $(2.42 \pm 0.01 \%)$. Thus, the addition of carrots can increase sensory acceptance as well as water and dietary fiber content.

Keywords : Pempek, Mackerel, Carrot, Nutritional Value

\section{https://doi.org/10.33860/jik.v15i2.488}

(C) 2021 by the authors. Submitted for possible open access publication under the terms and conditions of the Creative Commons Attribution (CC BY SA) license (https://creativecommons.org/licenses/by-sa/4.0/). 


\section{PENDAHULUAN}

Pempek dapat dikatakan sebagai makanan sumber protein hewani karena bahan utama pembuatan pempek adalah ikan. Penambahan sayur sebagai sumber serat pangan ke dalam pempek diharapkan dapat meningkatkan mutu gizi pempek dan membantu meningkatkan asupan serat pangan. Pada tahun 2007 masyarakat Indonesia hanya mengonsumsi sayur sebanyak $79 \%$ atau 95,47 kkal/kapita/hari dari anjuran $120 \mathrm{kkal} / \mathrm{kapita} / \mathrm{hari}$ menurut pola diet 2000 kkal. Bahkan konsumsi sayur masyarakat DKI Jakarta lebih rendah yaitu 59\% atau $71,56 \mathrm{kkal} / \mathrm{kapita} / \mathrm{hari}^{(1)}$. Dari penelitian lain juga dapat diketahui jumlah serat pangan yang dikonsumsi per hari oleh masyarakat DKI Jakarta sangat rendah yaitu hanya $36 \%$ atau 9 gram/hari dari anjuran 25 gram/hari ${ }^{(2)}$.

Wortel merupakan salah satu sayuran sumber serat pangan. $100 \mathrm{~g}$ wortel mengandung serat pangan sebanyak $6 \mathrm{~g}^{(3)}$. Jumlah tersebut mampu memenuhi 24\% kebutuhan serat harian. Menurut Wibowo et al., (2014), wortel mengandung serat pangan larut dan serat pangan tidak larut dalam jumlah tinggi. Serat pangan larut berperan dalam perbaikan kolesterol darah melalui penurunan kadar low density lipoprotein (LDL) dan peningkatan high density lipoprotein (HDL), serta mencegah penyakit cardiovasculer dan divertikulosis ${ }^{(4)}$. Kemudian, serat pangan tidak larut dapat mencegah disfungsi alat pencernaan. Selain itu, wortel juga merupakan sumber vitamin A, vitamin $\mathrm{C}$, vitamin $\mathrm{B}$, kalsium, zat besi, fosfor, seng, dan kalium ${ }^{(5)}$.

Wortel sangat mudah ditemukan di Indonesia dan dapat tumbuh di segala musim. Jenis sayur ini mampu bertahan pada penyimpanan dengan suhu $10{ }^{\circ} \mathrm{C}$ selama $2-6$ minggu $^{(6)}$. Hal ini dapat menjamin ketersedian sayur tersebut sebagai bahan tambahan dalam pengolahan pempek. Selain ketersediaan dan umur simpan sayur, berbagai zat gizi yang terkandung di dalam sayur tersebut juga diharapkan mampu meningkatkan kandungan gizi produk akhir pempek dalam penelitian ini. Penelitian ini mengkaji karakteristik nilai gizi serta penerimaan sensori pempek ikan tenggiri dengan penambahan wortel.

\section{METODE PENELITIAN Desain Penelitian}

Desain yang digunakan adalah penelitian eksperimental dengan Rancangan Acak
Lengkap (RAL) satu faktor yaitu variasi penambahan konsentrasi wortel $(0 \%, 20 \%$, $40 \%$, dan $60 \%$ ) dengan dua kali pengulangan.

\section{Preparasi Produk}

Wortel yang digunakan harus segar, tidak lecet, tidak lembek, tidak busuk, berwarna jingga kemerahan dan cerah. Sayur ini dibersihkan dan dicuci, kemudian diblansir dengan air panas (suhu $82-84^{\circ} \mathrm{C}$ ) selama $3-5$ menit untuk inaktivasi enzim yang dapat menyebabkan kerusakan jaringan tanaman. Selanjutnya, wortel dibelneder untuk memperoleh puree wortel yang halus.

Pembuatan pempek dengan penambahan wortel mengacu pada penelitian ${ }^{(7)}$. Satu lenjer pempek ikan tenggiri terdiri atas $45 \mathrm{~g}$ ikan tenggiri, $30 \mathrm{~g}$ tepung tapioka, $15 \mathrm{~g}$ air es, $3 \mathrm{~g}$ garam, dan wortel $(0 \mathrm{~g}, 9 \mathrm{~g}, 18 \mathrm{~g}, 27 \mathrm{~g})$. Penggunaan air es bertujuan agar adonan lebih mudah menyatu, pempek yang dihasilkan lebih kenyal tetapi tidak liat. Proses pembuatan pempek ikan tenggiri adalah dengan mencampurkan ikan tenggiri giling, air es, dan garam. Pencampuran dilakukan hingga adonan membentuk pasta. Campuran ikan (45 g), air es $(15 \mathrm{~g})$, dan garam $(3 \mathrm{~g})$ yang telah membentuk pasta ditambahkan puree wortel. Jumlah puree yang ditambahkan adalah $0 \%(0 \mathrm{~g}), 20 \%(9 \%)$, $40 \%$ (18 g), dan 60\% (27g), yang ditentukan berdasar jumlah total ikan tenggiri yang digunakan (45 g). Kemudian, tepung tapioka (30 g) ditambahkan sedikit demi sedikit hingga tercampur merata ke dalam adonan. Adonan kemudian dibentuk dan direbus dalam panci berisi air mendidih hingga mengapung, kemudian ditiriskan.

\section{Evaluasi Nilai Sensori}

Dua puluh lima panelis semi terlatih melakukan penilaian terhadap parameter sensori. Panelis yang terlibat harus memenuhi syarat: panelis bersedia, sehat fisik dan mental, tidak dalam keadaan kenyang ataupun lapar, dan tidak berpantang makan dan aleergi terhadap bahan yang digunakan dalam pembuatan produk. Penilaian menggunakan visual analog scale terhadap warna, aroma, tekstur, dan rasa dari produk.

Produk dengan penilaian sensori hedonik terbaik kemudian akan dilanjut dengan analisis fisik berupa tekstur dan warna, serta analisis zat gizi berupa kadar air, abu, protein, lemak, serat, karbohidrat. 


\section{Analisis Sifat Fisik}

Pengukuran tekstur dilakukan dengan alat texture analyzer yang terhubung pada komputer melalui program Texture ProLite. Kemudian, determinsai warna menggunakan sistem notasi warna Hunter menggunakan alat kolorimeter langsung dapat mencatat nilai-nilai $\mathrm{L}, \mathrm{a}, \mathrm{dan} \mathrm{b}$

\section{Analisis Zat Gizi}

Analisis kadar air, abu, protein, dan lemak berdasarkan metode analisis proksimat yang mengacu pada ${ }^{(8)}$. Kadar karbohidrat ditentukan melalui metode by difference ${ }^{(9)}$. Selanjutnya, kadar serat pangan ditentukan melalui metode enzimatis ${ }^{(10)}$.

\section{Analisis Data}

Manajemen data dilakukan dengan microsoft office 2010 for windows. Data dianalisis dengan menggunakan uji One Way Anova dengan derajat kepercayaan $95 \%$ dan uji lanjut Duncan.

\section{HASIL}

Hasil penilaian sensori pempek dengan penambahan puree wortel disajikan pada Tabel 1. Secara statistik, penambahan wortel mempengaruhi tingkat penerimaan hedonik warna, tekstur, dan rasa ( $\mathrm{p}<0.05$, namun tidak mempengaruhi aroma $(\mathrm{p}>0.05)$. Berdasarkan penilaian sensori oleh 25 panelis semi terlatih, diketahui bahwa formula F3 merupakan yang terbaik. Maka, produk formula F3 ini kemudian dianalisis lanjut terhadap parameter sifat fisik dan komponen zat gizi.

Analisis fisik dilakukan terhadap parameter tekstur dan warna. Hasil analisis tersaji pada Tabel 2. Penambahan wortel $40 \%$ (formula F3) terlihat memberikan pengaruh terhadap warna, namun tidak mempengaruhi tekstur pempek.

Analisis zat gizi yang dilakukan meliputi analisis proksimat (air, abu, lemak, protein, dan karbohidrat) dan kadar serat pangan. Nilai gizi pempek dengan penambahan $40 \%$ (18 g) wortel ditampilkan pada Gambar 1.

Berdasarkan Gambar 1, diketahui bahwa pempek dengan penambahan $40 \%$ wortel memiliki kadar air dan kadar serat pangan lebih tinggi dibandingkan dengan pempek kontrol. Namun, pada parameter kadar abu, protein, dan karbohidrat, pempek wortel ini cenderung memiliki komposisi yang lebih rendah dibandingkan pempek kontrol. Kedua produk ini juga diketahui memiliki kandungan lemak sangat rendah $(<0.02 \mathrm{~g})$.

Tabel 1. Penilaian Hedonik Pempek Wortel

\begin{tabular}{llllll}
\hline \hline \multirow{2}{*}{ Parameter } & \multicolumn{3}{l}{ Formula $*$} & \multirow{2}{*}{ Sig.** } \\
\cline { 3 - 5 } & F1 & F2 & F3 & F4 & \\
\hline \hline Warna & $6,3 \pm 1,7^{\mathrm{a}}$ & $5,9 \pm 1,9^{\mathrm{a}}$ & $6,7 \pm 1,7^{\mathrm{ab}}$ & $7,4 \pm 1,5^{\mathrm{b}}$ & 0,03 \\
Aroma & $4,9 \pm 2,3^{\mathrm{a}}$ & $5,2 \pm 2,5^{\mathrm{a}}$ & $5,8 \pm 2,4^{\mathrm{a}}$ & $6,0 \pm 2,2^{\mathrm{a}}$ & 0,38 \\
Tekstur & $5,2 \pm 2,3^{\mathrm{a}}$ & $5,8 \pm 1,9^{\mathrm{ab}}$ & $6,7 \pm 1,7^{\mathrm{b}}$ & $6,2 \pm 1,9^{\mathrm{ab}}$ & 0,04 \\
Rasa & $5,2 \pm 2,2^{\mathrm{a}}$ & $5,2 \pm 2,0^{\mathrm{a}}$ & $6,8 \pm 1,6^{\mathrm{b}}$ & $6,3 \pm 1,8^{\mathrm{ab}}$ & 0,01 \\
\hline
\end{tabular}

Keterangan : $*=$ mean $\pm \mathrm{SD}, * *=$ signifikan pada $\alpha=0,05$

Tabel 2. Sifat Fisik Pempek Wortel

\begin{tabular}{clll}
\hline \hline \multirow{2}{*}{ Kategori } & Jenis Pempek & \multirow{2}{*}{ SNI* } \\
\cline { 2 - 3 } & Pempek Kontrol & Pempek Wortel & \\
\hline \hline Tektur & Kenyal & Kenyal & Kenyal \\
Warna & Putih buram & Kuning kemerahan & Normal \\
\hline \hline
\end{tabular}

* SNI 01-3819-1995 


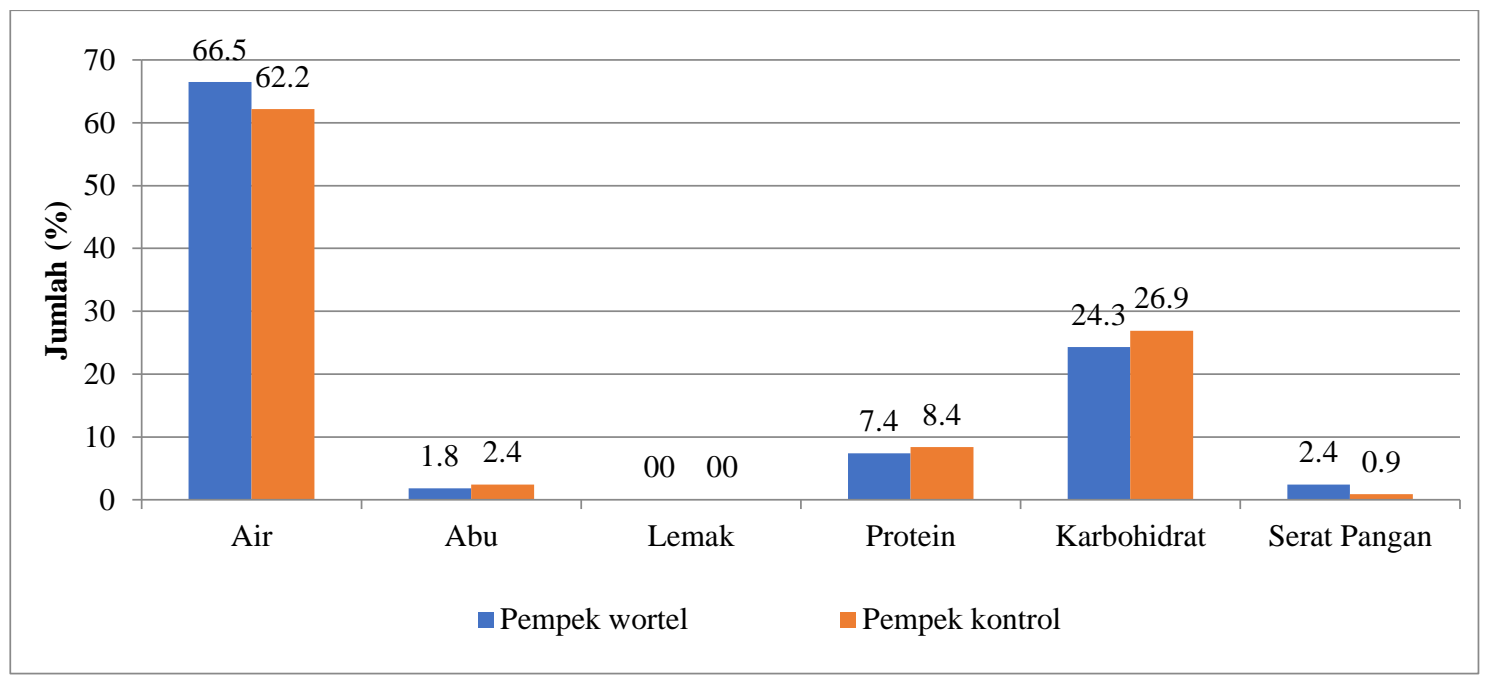

Gambar 1. Komposisi zat gizi

\section{PEMBAHASAN}

Hasilnya menunjukkan bahwa produk pempek sayur terbaik adalah produk pempek wortel yaitu pempek wortel F3. Produk pempek wortel F3 adalah produk pempek ikan tenggiri dengan penambahan $40 \%$ wortel. Produk pempek wortel memiliki warna jingga cerah, aroma khas ikan, tekstur kenyal, dan rasa gurih. Produk pempek wortel mengandung air 66,52 \pm $0,57 \%$, abu $1,77 \pm 0,05 \%$, lemak $<0,02 \%$, protein $7,43 \pm 0,01 \%$, karbohidrat $24,25 \pm$ $0,63 \%$, serta kadar serat pangan $2,42 \pm 0,01 \%$.

\section{Nilai Sensori}

Warna merupakan faktor dominan yang dapat meningkatkan penerimaan produk di dunia industri, termasuk industri makanan ${ }^{(11)}$. Hasil analisis statistik pada penelitian ini menunjukkan bahwa ada pengaruh yang signifikan $(\mathrm{p} \leq 0,05)$ antara penambahan wortel dengan tingkat kesukaan panelis berdasarkan parameter warna dan karakteristik organoleptik berdasarkan parameter mutu warna. Produk pempek kontrol memiliki warna putih kecoklatan. Hasil penelitian ini menunjukkan bahwa penambahan wortel mampu meningkatkan mutu produk pempek wortel. Semakin tinggi konsentrasi penambahan wortel pada pempek ikan tenggiri menyebabkan perubahan warna menjadi semakin jingga karena tingginya kandungan karotenoid pada wortel. Wortel mengandung senyawa karotenoid (provitamin A) yang menyebabkan warna kuning kemerahan sampai jingga. Wortel dapat berfungsi sebagai pewarna alami sehingga dapat menghasilkan produk pempek dengan warna yang lebih menarik. Dwiwati
(2014) menyatakan bahwa warna kuning atau jingga pada wortel adalah akibat $\alpha$ - dan $\beta$ karoten, pigmen warna yang menghasilkan warna jingga dan kuning pada buah-buahan dan sayur-sayuran $^{(12)}$.

Hasil analisis statistik pada penelitian ini menunjukkan bahwa tidak ada pengaruh yang signifikan $(p>0,05)$ antara penambahan wortel dengan tingkat kesukaan panelis berdasarkan parameter aroma dan karakteristik organoleptik berdasarkan parameter mutu aroma. Wibowo, et al. (2014) menyatakan bahwa aroma wortel tidak memengaruhi minat dan tingkat kesukaan panelis pada produk nugget tempe ${ }^{(4)}$. Penambahan wortel pada pempek mampu menurunkan nilai rerata mutu aroma khas ikan karena aroma khas ikan melebur dengan aroma segar khas wortel. Namun penurunan nilai rerata ini tidak signifikan berbeda secara statistik. Hal ini dikarenakan wortel tidak menghasilkan aroma yang tajam untuk menutupi aroma ikan pada pempek.

Kekenyalan pempek dihasilkan dari perpaduan yang tepat antara daging ikan, tepung tapioka dan komposisi air es. Selain itu, proses pengolahan terutama pada tahap pencampuran bahan dan pengulenan juga sangat menentukan tekstur pempek yang dihasilkan. Hasil analisis statistik pada penelitian ini menunjukkan bahwa ada pengaruh yang signifikan $(\mathrm{p} \leq 0,05)$ antara penambahan wortel dengan tingkat kesukaan panelis berdasarkan parameter tekstur. Namun penambahan wortel pada pempek tidak memengaruhi (p >0,05) karakteristik organoleptik pempek wortel berdasarkan parameter mutu tekstur. Produk pempek kontrol (tanpa penambahan wortel) memiliki tekstur 
yang kenyal. Penambahan wortel mampu meningkatkan kekenyalan produk pempek wortel hingga konsentrasi penambahan $40 \%$ wortel dan menurun pada konsentrasi penambahan $60 \%$ wortel. Hal ini memengaruhi tingkat kesukaan panelis pada produk pempek wortel berdasarkan parameter tekstur yang juga meningkat hingga konsentrasi penambahan $40 \%$ wortel. Peningkatan kekenyalan ini diduga karena tingginya kadar air pada wortel. Kadar air berbanding terbalik dengan tingkat kekerasan pada suatu produk. Semakin tinggi kadar air, semakin rendah tingkat kekerasan produk. Sebalikya, semakin sedikit kadar air dalam produk, semakin tinggi tingkat kekerasannya.

Hasil analisis statistik pada penelitian ini menunjukkan bahwa ada pengaruh yang signifikan $(p \leq 0,05)$ antara penambahan wortel dengan tingkat kesukaan panelis berdasarkan parameter rasa. Produk pempek kontrol memiliki rasa yang gurih, sedangkan wortel segar memiliki rasa yang manis. Ketika rasa manis pada wortel bercampur dengan rasa gurih pada pempek akan menghasilkan produk pempek wortel yang semakin gurih. Penambahan wortel mampu meningkatkan kesukaaan panelis pada parameter rasa hingga konsentrasi penambahan $40 \%$ wortel dan menurun pada konsentrasi penambahan $60 \%$ wortel. Panelis tidak menyukai pempek dengan rasa terlalu gurih yang didominasi oleh rasa ikan maupun pempek dengan rasa yang terlalu didominasi oleh rasa wortel.

\section{Karakteristik Fisik}

Analisis fisik pada produk pempek sayur dilakukan pada 4 produk yaitu produk pempek kontrol dan pempek wortel (formula F3) yang merupakan produk dengan tingkaat penerimaan sensori terbaik.

Hasil analisis fisik yang dilakukan di laboratorium berdasarkan parameter tekstur diketahui bahwa kedua produk memiliki tekstur dengan kategori yang sama, yaitu kenyal. Penambahan sayur pada pempek ikan tenggiri tidak memberikan perbedaan pada tekstur pempek wortel.

Hasil analisis fisik berdasarkan parameter warna menunjukkan adanya perbedaan. Produk pempek kontrol memiliki warna putih kecoklatan, sedangkan pempek wortel memiliki warna kuning kemerahan. Hal ini disebabkan oleh jenis adanya kandungan zat warna pada wortel berupa beta-karoten.

\section{Komposisi zat gizi}

Analisis zat gizi dilakukan terhadap pempek kontrol dan pempek wortel (formula F3) yang memiliki tingkat penerimaan sensori terbaik. Air dalam bahan makanan berperan sebagai pelarut, transportasi zat gizi, penstabil pembentukan boiopolimer, dan sebagainya ${ }^{(13)}$. Kandungan air pada makanan berbeda-beda. Kadar air pada pempek kontrol lebih rendah bila dibandingkan dengan pempek wortel. Peningkatan kadar air pada pempek wortel dipengaruhi oleh kadar air wortel yang ditambahkan.

Abu merupakan residu komponen anorganik setelah pembakaran ataupun oksidasi komponen organik ${ }^{(14)}$. Nilai kadar abu menurun dengan adanya penambahan wortel pada pempek. Kandungan air yang tinggi pada wortel diduga mempengaruhi niai kadar abu pempek. Kadar abu umumnya akan semakin rendah bila kandungan air pada suatu produk semakin tinggi. Hasil penelitian ini sejalan dengan penelitian Wibowo, et al. (2014) yang menunjukkan adanya penurunan kadar abu seiring dengan peningkatan penambahan konsentrasi wortel pada produk nugget tempe ${ }^{(4)}$.

Lemak salah satunya terdiri dari asam lemak essensial adalah asam lemak yang dibutuhkan oleh tubuh untuk pertumbuhan dan fungsi normal semua jaringan, sedangkan tubuh tidak dapat mensintesisnya. Dari hasil analisis proksimat kadar lemak menunjukkan bahwa semua produk pempek mengandung lemak dengan kadar $<0,02 \%$. Penambahan wortel pada pempek tidak memengaruhi kadar lemak pempek. Selain juga, Almatsier (2008) menyebutkan bahwa ikan termasuk dalam golongan sumber protein hewani rendah lemak $^{(3)}$.

Protein teridiri atas asam amino yang berperan penting dalam pertumbuhan sel-sel dan jaringan otot. Protein juga bermanfaat dalam meningkatkan fungsi otak ${ }^{(3)}$. Ikan tenggiri kaya akan protein dengan komposisi asam amino yang sangat baik dalam memenuhi kebutuhan gizi manusia. Hasil analisis proksimat kadar protein produk pempek wortel menunjukkan bahwa kadar protein lebih tinggi adalah pada pempek kontrol. Penambahan wortel menurunkan kadar protein pempek sayur.

Karbohidrat berfungsi sebagai penghasil energi bagi tubuh dan menunjang aktivitas anak 
yang mulai aktif bergerak. Dengan demikian, sangat penting untuk mengetahui kadar karbohidrat dari bahan makanan atau produk pangan yang kita konsumsi. Hasil analisis kimia kadar karbohidrat produk pempek pada penelitian ini menunjukkan bahwa pempek kontrol memiliki kadar karbohidrat lebih tinggi dibandingkan pempek wortel. Pempek mengandung karbohidrat yang cukup tinggi karena terbuat dari bahan baku tepung tapioka. Wortel bukan merupakan sumber karbohidrat. Dengan demikian, penambahan wortel pada pempek membuat konsentrasi tepung tapioka semakin kecil sehingga kadar karbohidrat semakin menurun pada pempek wortel.

Serat pangan merupakan polisakarida yang sulit dicerna oleh sistem gastrointestinal bagian atas tubuh manusia. Serat pangan sangat bermanfaat bagi kesehatan terutama dalam mencegah penyakit tidak menular seperti obesitas, penyakit jantung, dan lain-lain. Konsumsi bahan makanan atau produk pangan sumber serat pangan dapat menurunkan kolesterol total, LDL, trigliserida dan indeks atherogenik $^{(15)}$. Mengingat besarnya manfaat serat pangan, sangan penting untuk mengetahui sumber serat pangan dan kadar serat pangan dalam bahan makanan atau produk pangan. Penambahan sayur sebagai sumber serat pangan pada pempek ikan tenggiri mampu meningkatkan kadar serat pangan.

Produk pempek sayur yang dihasilkan pada penelitian ini memiliki berat sekitar 100 gram. Dalam konsumsi normal, pempek kontrol dengan kadar serat pangan $0,90 \pm 0,01 \%$ mampu memenuhi kebutuhan serat pangan harian sebesar 2,8 - 4,5\%. Pempek wortel dengan kadar serat pangan $2,42 \pm 0,01 \%$ mampu memenuhi kebutuhan serat pangan harian sebesar 6,9-12,1\%. Suatu bahan makanan atau produk pangan dapat dikatakan sebagai sumber zat gizi yang baik bila mengandung $10-19 \%$ kebutuhan zat gizi harian dalam 1 porsi penyajian ${ }^{(16)}$. Dengan demikian, pempek sayur yang dihasilkan dalam penelitian ini termasuk dalam sumber serat pangan yang baik.

\section{KESIMPULAN DAN SARAN}

Penambahan puree wortel senilai $40 \%$ pada pempek ikan tenggiri dapat meningkatkan penerimaan sensori baik pada parameter warna, aroma, tekstur, dan rasa. Penambahan pada taraf tersebut mampu meningkatkan kadar air, dan serat pangan pempek.

Pada penelitian selanjutnya, disarankan untuk melakukan uji lanjutan yaitu uji daya simpan pada produk pempek sayur agar keamaan produk pempek sayur dapat lebih terjamin. Selain itu, disarankan juga untuk melakukan uji lanjutan berupa analisis kadar mineral, serta kadar zat warna dan antioksidan berupa karotenoid, klorofil, dan antosianin.

\section{DAFTAR PUSTAKA}

1. Raharto A, Noveria M, Fitranita NFN. Konsumsi Sayur dan Buah di Masyarakat dalam Konteks Pemenuhan Gizi Seimbang. Jurnal Kependudukan Indonesia. 2008 Dec 31;3(2):97-119.

2. Utami S. Hubungan antara Aktifitas Fisik, Kebiasaan Konsumsi Serat, dan Faktor Lain dengan Kejadian Obesitas pada Siswa SD Islam Annajah, Jakarta Selatan [Skripsi]. [Depok]: Universitas Indonesia; 2009.

3. Almatsier S. Penuntun Diet. Jakarta: Gramedia Pustaka Utama; 2008.

4. Wibowo A, Hamzah F, Johan VS. Pemanfaatan Wortel (Daucus carota L.) dalam Meningkatkan Mutu Nugget Tempe. Jurnal Sagu. 2014;13(2):27-34.

5. Evianty ST, Sari NI, Sumarto. Kajian Penerimaan Konsumen terhadap Empekempek Ikan Jelawat (Leptobarbus hoevenii) dengan Penambahan Wortel (Daucus carota). Jurnal Online Mahasiswa. 2014;1-14.

6. Samad MY. Pengaruh Penanganan Pasca Panen terhadap Mutu Komoditas Holtikultura. Jurnal Sains dan Teknologi Indonesia. 2006;8(1):31-6.

7. Saputri NE, Hidayah N, Muttalib YS, Salam A, Rahmawati, Septiyanti. Sensory acceptance and physicochemical profiles of Pempek Made with Narrow-barred Spanish Mackerel Fish Enriched with Broccoli and Red Cabbage. IOP Conf Ser: Earth Environ Sci. 2021 Jul;807(2):022068.

8. AOAC. Official methods of analysis, 19th edition. Association of Official Analytical Chemists. Official methods 968.08, 956.01, and 968.08. Arlington (VA); 2012.

9. Winarno FG. Kimia pangan dan gizi. Jakarta (ID): Gramedia; 2008.

10. de Almeida Costa GE, da Silva QueirozMonici K, Pissini Machado Reis SM, de Oliveira AC. Chemical composition, dietary fibre and resistant starch contents of raw and cooked pea, common bean, chickpea and lentil legumes. Food Chemistry. 2006 Feb 1;94(3):327-30.

11. Fujiana F, Gres K, Muttalib YS, Salam A, Wirawanti IW, Fadly D. Fresh noodles enriched with Coleus amboinicus Lour leaves to lower the premenstrual syndrome level. IOP Conf Ser: Earth Environ Sci. 2021 Jul;807(2):022064. 
12. Dwiwati R. Pemanfaatan Ekstrak Wortel (Daucus Carota) Dan Buah Waluh (Cucurbita moschata) Sebagai Bahan Pengawet Alami Bakso Daging [Internet] [Skripsi]. [Solo]: Universitas Muhammadiyah Surakarta; 2014 [cited 2021 Aug 23]. Available from: http://eprints.ums.ac.id/28743/

13. Fadly D, Purwayantie S. Karakteristik Sensori dan Kimiawi Non-Meat Burger Patties Berbasis Kearifan Pangan Lokal. Ghidza: J Gizi dan Kesehat. 2019;3(1):19-24.

14. Fadly D, Kusharto CM, Kustiyah L, Suptijah P. Physicochemical Characteristics of Carboxymethyl Chitosan from Silkworm (Bombyx mori L.) Pupa International Journal of Sciences: Basic and Applied Research (IJSBAR). IJSBAR. 2017;31(1):204-12.

15. Astawan M, Wresdiyati T, Hartanta AB. The Utilization of Seaweed as a Source of Dietary Fiber to Decrease the Serum Cholesterol in Rats. HAYATI Journal of Biosciences. 2005 Mar 1;12(1):23-7.

16. McGuire M, Beerman KA. Nutritional Sciences: From Fundamentals to Food. Cengage Learning; 2012. 774 p. 